Dhaka Univ. J. Sci. 65(1) 73-76, 2017 (January)

\title{
Human Trafficking and Displacement in South Asia: An Econometric Analysis Tanjina Rahman ${ }^{1}$, Md. Israt Rayhan ${ }^{1 *}$ and Nayeem Sultana ${ }^{2}$ \\ ${ }^{1}$ Institute of Statistical Research and Training (ISRT)), Dhaka University, Dhaka-1000, Bangladesh \\ ${ }^{2}$ Department of Development Studies, Dhaka University, Dhaka-1000, Bangladesh
}

(Received: 21 September 2016; Accepted: 22 November 2016)

\begin{abstract}
Human trafficking has received increased media and national attention. Despite concerted efforts to combat human trafficking, the trade in persons persists and in fact continues to grow. This paper describes the relationship and distinction between trafficking and ethnic fragmentation, conflict, internally displaced person by different measures of control. To explain the relationship between these factors, this study uses a Probit regression model. It appears that ethnic conflict leads the internal displacement of individuals from networks of family and community, and their access to economic and social safety nets.
\end{abstract}

Keywords: Trafficking, Displacement, Probit, Conflict, Econometrics.

\section{Introduction}

Human trafficking has an impact on the individuals. More than 130 countries are affected by human trafficking. Globally, 29 percent of human trafficking occurs after crossing a border. Human traffickers target economic migrants and those migrating because of lack of education, political and climate instability, discrimination and conflict (UN GIFT ${ }^{1}$ ).

Every stage of the trafficking process can involve physical, sexual and psychological abuse and violence, deprivation and torture, the forced use of substances, manipulation, economic exploitation and abusive working and living conditions. Some push factors behind asylum migration, namely (i) repression of minorities or ethnic conflict, (ii) civil war, (iii) high numbers of internally displaced persons (IDPs) relative to total population, (iv) poverty as reflected in low per capita income, (v) low position on the Human Development Index (HDI), (vi) low life expectancy, (vii) high population density and (viii) high adult literacy rate; mirror closely the push factors that induce trafficking, namely (i) poverty, (ii) lack of educational opportunities and (iii) armed conflict (Castles and Loughna ${ }^{2}$; Akee et al. ${ }^{3}$ ). Perry and McEwing ${ }^{4}$ have found that social determinants are central to the processes that mitigate and facilitate the sale and exploitation of women and children in Southeast Asia. Specifically, the facilitation of education and empowerment, along with the creation and enforcement of effective policies, could lessen the vulnerability of women and children to modern-day slavery. Koettl ${ }^{5}$ illustrated that whenever people are forced or lured into exploitation - no matter if movement of victims is involved - it is considered human trafficking. Arhin ${ }^{6}$ suggested new conceptual tools to understand the dynamics and relationships between trafficking in persons and diaspora networks. A diaspora approach provides a more nuanced and in-depth mode of analyzing human-trafficking cases, and takes into account the intersections between traffickers, victims and diaspora communities within the human-trafficking process.

In South Asia, there are many countries used as origin, transit and destination countries for trafficking. Victims are sent to other countries in the region and to other parts of the world. Even more prevalent is the movement of persons within the countries for exploitation in various forms. Even though there are no definite numbers of victims, it is estimated that 150,000 victims are trafficked from the South Asia region annually $\left(\mathrm{WDI}^{7}\right)$. Many studies have revealed that trafficking in women and children is on the rise in Asia. Bangladesh is a source and transit country for men, women, and children subjected to trafficking in persons, specifically forced labor and forced prostitution. A significant share of Bangladeshi victims are men recruited for work overseas with fraudulent employment offers who are subsequently exploited under conditions of forced labor or debt bondage. Children both boys and girls are trafficked within Bangladesh for commercial sexual exploitation, bonded labor, and forced labor. In Nepal, Afghanistan, Pakistan and the Philippines, displaced children are at risk of child labor, trafficking and forced recruitment $\left(\mathrm{WDI}^{7}\right)$. The peculiar situation in South Asia is that communities of same ethnic group are spread across the international borders. As the displacements in Afghanistan and Myanmar have direct implications for the broader South Asian context. Pakistan, India and Bangladesh, three important countries of the subcontinent, face displacements simultaneously due to development, conflicts and natural disasters. Pakistan, Afghanistan and India had the highest number of reported IDPs, accounting for more than a third of the regions displaced population.

Any economic or social policy that is deemed to confer additional benefits purely to a particular ethnic group can be a cause for dissent and conflict. An additional cause of ethnic conflict stems from the inability of international, national and regional powers to adequately provide security for minority groups. However, it can be argued that ethnic fragmentation (or the share of an ethnic group in the total population) within a country does not necessarily imply dissent even in the face of perceived unjust economic and social policies (Akee et al. $^{3}$ ). Lindstrom and Moore ${ }^{8}$ in fact find support for the hypothesis that ethnic fragmentation is positively correlated with conflict. About 40 million people are displaced globally with 15 million refugees (UNHCR ${ }^{9}$ ). Therefore, the specific objectives of this study are: to determine the link between ethnic conflict and human trafficking, to determine the relationship between ethnic fragmentation and human trafficking, to assess the efficacy and relevance with the issues of displacement in South Asia.

\footnotetext{
*Author for correspondence.e-mail: israt@ isrt.ac.bd
} 


\section{Data and Methodology}

To determine the relationship between internally displaced persons and refugees, ethnic fragmentation and conflict, data are collected from various sources described below. Data on incidence of trafficking are compiled from countryby-country descriptive accounts and the number of Internally Displaced Persons (IDPs) and IDP-like situations are data collected by United Nations High Commissioner for Refugees (UNHCR ${ }^{9}$ ). Conflict measures are collected from the Uppsala Conflict Data Program (UCDP)/International Peace Research Institute, Oslo (PRIO) Armed Conflict Dataset $^{10}$. The Gross Domestic Product (GDP) and the landlocked indicator were obtained from the World Development Indicator $\left(\mathrm{WDI}^{7}\right)$. From the review of literature this study found that trafficking is the binary response variable. The description of other variables is given below in the table.

\section{Table 1. Description of Variables}

\begin{tabular}{|c|c|}
\hline Variable & Description of variable \\
\hline \multicolumn{2}{|l|}{ Human trafficking } \\
\hline trafficking & $\begin{array}{l}\text { Incidence of trafficking(host- } \\
\text { source country),(0/1) }\end{array}$ \\
\hline \multicolumn{2}{|l|}{ Fragmentation } \\
\hline ethnic & ethnic fractionalization index \\
\hline religion & religious fractionalization index \\
\hline language & language fractionalization index \\
\hline \multicolumn{2}{|l|}{ IDPs/Refugees } \\
\hline refugees/IDPs & $\begin{array}{l}\text { refugee and internally displaced } \\
\text { persons, }(0 / 1)\end{array}$ \\
\hline \multicolumn{2}{|l|}{ Conflict } \\
\hline cumulative intensity & $\begin{array}{l}\text { Cumulative intensity level of } \\
\text { conflict }\end{array}$ \\
\hline intensity & $\begin{array}{l}\text { intensity level of conflict: 1- } \\
\text { minor, 2- war }\end{array}$ \\
\hline count & $\begin{array}{l}\text { Number of conflicts within a } \\
\text { country }\end{array}$ \\
\hline
\end{tabular}

Here, a country is designated as a Host country for trafficked victims only if 747 cases were reported in the past year. Country host-source pairs of trafficking are coded from these above reports for the year 2015.

The variables fragmentation measures are taken from Akee et $a .^{3}$, where fragmentation (ethnic, religious or linguistic) is defined as $\operatorname{frag}_{j}=1-\sum_{i=1}^{N} S_{i j}^{2}$, where $S_{i j}$ is the share of group $i,(i=1,2, \ldots, N)$ in country $j$. Ethnic, religious and language fractionalization cover a larger range of countries and various aspects of fragmentation. As Akee et $a{ }^{3}$ discuss, these three indices are correlat ed and this study employs them separately in the estimations.

For various measures of conflict in our estimations, this study uses two measures that capture the intensity of conflict: (i) the cumulative intensity dummy takes into account the history of the conflict. It takes the value 0 if the conflict has resulted in less than 1,000 battle-related deaths and 1 otherwise and (ii) the level intensity of conflict is measured by distinguishing between either a minor conflict or a war (where a minor conflict has less than 25 battlerelated deaths per year for every year in the period, while a war is defined as 1 where more than 25 battle-related deaths per year for every year in the period). A count measures the number of conflicts within a country. Finally, a more complex measure is utilized that differentiates between the types of conflict into three categories.

To explain the behavior of a dichotomous dependent variable this study has to use a suitably chosen CDF. The estimating model that emerges from the normal CDF is popularly known as the Probit model $\left(\right.$ Greene $\left.^{11}\right)$, uses binomial response variables. In the Probit model, the inverse standard normal distribution of the probability is modeled as a linear combination of the predictors. Considering a latent variable, $y_{i}^{*}=X_{i}^{T} \beta+\varepsilon_{i}$, this model linearly depends on $X_{i}$ and the error term $\varepsilon_{i}$, here $y_{i}=1$ if the latent variable is positive and 0 otherwise, now the form is, $y_{i}=\left\{\begin{array}{l}0 ; y_{i}^{*}<0 \\ 1 ; y_{i}^{*}>0\end{array}\right.$

The latent variable is interpreted as the utility difference between choosing $y_{i}=1$ and 0 . The probability that can be derived from the latent variable and the decision $y_{i}=1$ rule.

$$
\begin{aligned}
p\left(y_{\mathrm{i}}\right. & \left.=1 \mid x_{\mathrm{i}}\right)=p\left(y_{i}^{*}>0 \mid x_{i}\right) \\
& =p\left(x_{i}^{T} \beta+\varepsilon_{i}>0 \mid x_{\mathrm{i}}\right) \\
& =p\left(\varepsilon_{i}>-x_{i}^{T} \beta \mid x_{\mathrm{i}}\right) \\
& =1-\Phi\left(\frac{-x_{i}^{T} \beta}{\sigma}\right) \\
& =\Phi\left(\frac{x_{i}^{T} \beta}{\sigma}\right)
\end{aligned}
$$

Assuming that the error term has a standard normal distribution, $\varepsilon_{i} \sim N(0,1)$, we have the equation, $\pi=\Phi\left(\eta_{i}\right)$. Where $\Phi$ is the standard normal CDF. The inverse transformation which gives the linear prediction as a function of the probability is, $\eta_{i}=\Phi^{-1}(\pi)$, The transformation function in the Probit model is the CDF of the standard normal distribution.

$$
\begin{aligned}
& p\left(y_{\mathrm{i}}=1 \mid x_{\mathrm{i}}\right)=\Phi\left(\frac{x_{i}^{T} \beta}{\sigma}\right) \\
& =\int_{-\infty}^{x_{i}^{T} \beta} \Phi(z) d z
\end{aligned}
$$

If the error term has a standard normal distribution, then it is the Probit model.

\section{Analyses and Results}

To determine the link between ethnic conflicts and international trafficking, we estimate the direct effect of ethnic fragmentation, various types of external and internal conflicts, presence of IDPs/refugees in a source country on the incidence of trafficking between countries.

This model is presented below:

$$
\begin{aligned}
\text { trafficking }_{i j}= & \alpha_{1}+\beta_{1} \text { frag }_{i}+\beta_{2} \text { frag }_{i}^{2} \\
& +\beta_{3} \text { refugeeid }_{i} \\
& +\beta_{4} \text { conflict }_{i}+\varepsilon_{i j}
\end{aligned}
$$


Where trafficking is the binary dependent variable for the incidence of trafficking from country $i$ to country $j$ (source $i$ to host $\mathrm{j}$ ). This variable takes the value 1 if an incidence of trafficking from country $\mathrm{i}$ to country $\mathrm{j}$ is reported and 0 otherwise. The variable frag measures fragmentation in the source country of trafficking. It is measured continuously from 0 to 1 while $\mathrm{frag}^{2}$ is the squared value of the fragmentation variable. Three measures, ethnic, religious and language fragmentation, are included in turn in the different regression specifications. The dummy variable refugeeidp indicates the presence of refugees as well as internally displaced persons in the source country. The variable conflict captures the various measures of conflict in a source country. This study includes these various measures in separate regression specifications for each fragmentation measure (ethnic, religious and linguistic).

Table 2. Probit regression : Marginal Effects of Ethnic, Religion and Language Fragmentation

\begin{tabular}{|c|c|c|c|c|c|}
\hline $\begin{array}{l}\text { Variables } \\
\text { (Ethnic) }\end{array}$ & $\begin{array}{c}\text { Estimated Coefficient } \\
\text { [SD error] }\end{array}$ & $\begin{array}{l}\text { Variables } \\
\text { (Religion) }\end{array}$ & $\begin{array}{c}\text { Estimated Coefficient } \\
\text { [SD error] }\end{array}$ & $\begin{array}{l}\text { Variables } \\
\text { (Language) }\end{array}$ & $\begin{array}{c}\text { Estimated } \\
\text { Coefficient } \\
\text { [SD error] }\end{array}$ \\
\hline \multirow[t]{2}{*}{ Ethnic } & $5.20 *$ & Religion & $4.18 * *$ & Language & $8.93 * *$ \\
\hline & {$[2.12]$} & & [1.58] & & {$[3.31]$} \\
\hline \multirow[t]{2}{*}{$\begin{array}{l}\text { Ethnic } \\
\text { squared }\end{array}$} & $-6.33 * *$ & $\begin{array}{l}\text { Religion } \\
\text { squared }\end{array}$ & $-5.89 *$ & Language squared & $-9.64 *$ \\
\hline & {$[2.43]$} & & {$[2.11]$} & & {$[4.36]$} \\
\hline \multirow[t]{2}{*}{ Refugeeidp } & 1.08 & Refugeeidp & .28 & Refugeeidp & $2.54 *$ \\
\hline & {$[.61]$} & & {$[.53]$} & & {$[1.08]$} \\
\hline \multirow[t]{2}{*}{ Cum-intensity } & -.97 & Cum-intensity & -2.32 & Cum-intensity & -3.92 \\
\hline & [.69] & & {$[1.84]$} & & [2.39] \\
\hline \multirow[t]{2}{*}{ Intensity } & .75 & Intensity & $5.81 *$ & Intensity & 4.53 \\
\hline & {$[.53]$} & & {$[2.60]$} & & [2.91] \\
\hline \multirow[t]{2}{*}{ Count } & -.19 & Count & .24 & Count & .42 \\
\hline & {$[.14]$} & & {$[.14]$} & & {$[.25]$} \\
\hline
\end{tabular}

*significant at $10 \%, * *$ significant at $5 \%$ and $* * *$ significant at $1 \%$ level of significance.

The impact of ethnic, religion, and language fragmentation on the incidence of trafficking have been estimated the various conflict measures. From the above table 2, it is illustrated that higher ethnic fragmentation increases the likelihood of trafficking from a country while the coefficient on the squared term on ethnic fragmentation is negative and significant under all the conflict measures. This implies that ethnic fragmentation increases the likelihood of trafficking but at a decreasing rate. A possible explanation of this result might be that, higher ethnic fragmentation allows middleman or traffickers to easily target members of different ethnic groups and take advantages of the limited information. A higher likelihood of trafficking is associated positively but insignificantly with a host country under the cumulative intensity, level of intensity and count measures of conflict. The presence of IDPs/refugees in the host country has positive impact the likelihood of trafficking.

\section{Conclusion}

Human trafficking is an issue of major international discussion and concern. This study is an attempt to determine the relationship between ethnic, religious, fragmentation, and different types of conflict. In order to study the qualitative and binary response variable, probit regression model is used. By estimating the various conflict measures this study found that ethnicity, religion, language, refugee status and level intensity are significant, and that matches with relevant literature (Akee et al. ${ }^{3}$, Arhin $^{6}$ ).

Human trafficking involves transnational movement of people, one important related area of debate is internally displaced persons (IDPs). Another concern is ethnic conflicts. Trafficking for commercial sexual exploitation is the most virulent form of trafficking in the region. The movement of young girls from South Asian countries is common, taking place either between countries or within countries. There is further movement to the Middle East as well as other destinations. Internal displacement due to conflict in some countries, poverty and lack of employment opportunities increase the vulnerability to being trafficked.

Every stage of the trafficking process can involve physical, sexual and psychological abuse and violence, deprivation and torture, the forced use of substances, manipulation, economic exploitation and abusive working and living conditions. Unlike most other violent crime, trafficking usually involves prolonged and repeated trauma. The situation of IDPs has been more acute compared to refugees or migrants in the absence of protection from international organizations or states pursuing concrete policies in this regard. 


\section{References}

1. UN GIFT (Global Initiative to Fight Human Trafficking), 2012. An Introduction to Human Trafficking: Vulnerability, Impact and Action. www.ungift.org.

2. Castles, S. and S. Loughna, 2003. Trends in Asylum Migration to Industrialized Countries: 1990-2001; Discussion Paper No. 2003/31. World Institute of Development Research (WIDER), Helsinki.

3. Akee, R., A. K. Basu, A. Bedi and N. Chau, 2010. Combating trafficking in Women and Children: A Review of International and National legislation. Cooperation Failures and perverse Economic Incentives. 2, 1-24.

4. Perry, K. M. and L. McEwing, 2013. How do social determinants affect human trafficking in Southeast Asia, and what can we do about it? A systematic review. Health and Human Rights.15 (2), 138-159.

5. Koettl, J., 2009. Human Trafficking, Modern Day Slavery, and Economic Exploitation. SP Discussion Paper, No. 0911, World Bank.
6. Arhin, A., 2016. A Diaspora Approach to Understanding Human Trafficking for Labor Exploitation. Journal of Human Trafficking. 2 (1), 78-98.

7. World Development Indicators (WDI), 2015. Trafficking in Persons Report. Washington DC: The World Bank.

8. Lindstrom, R. and W. H. Moore, 1995. Deprived, Rational or Both? Minorities Rebel Revisited, Journal of Political and Military Sociology. 23, 167-190.

9. UNHCR, 2015. The State of the Worlds Refugees: Fifty Years of Humanitarian Action. Oxford: Oxford University Press.

10 UCDP/PRIO, 2015. UCDP/PRIO Armed Conflict Dataset. ww.ucdp.uu.se/database, last accessed $30^{\text {th }}$ June 2016.

11. Greene, W. H., 2013. Econometric Analysis, Fifth edition, Pearson, New York University. 